\title{
ANALISIS AIR LARIAN \\ DI WILAYAH JALAN TEMANGGUNG TILUNG KOTA PALANGKA RAYA PROVINSI KALIMANTAN TENGAH
}

\author{
Yosua Lama Lewa \\ Jurusan/Program Studi Teknik Sipil, Fakultas Teknik, Universitas Palangka Raya \\ Jln. Hendrik Timang, Palangka Raya, e-mail: yosua.cawer@gmail.com \\ Haiki Mart Yupi \\ Jurusan/Program Studi Teknik Sipil, Fakultas Teknik, Universitas Palangka Raya \\ Jln. Hendrik Timang, Palangka Raya, e-mail: haiki.yupi@yahoo.com \\ Nomeritae \\ Jurusan/Program Studi Teknik Sipil, Fakultas Teknik, Universitas Palangka Raya \\ Jln. Hendrik Timang, Palangka Raya, e-mail: rita_busu@yahoo.co.id
}

\begin{abstract}
Temanggung Tilung Road is one of the roads that often experience inundation. The development of the population in the city of Palangka Raya resulted in increased density of settlements and land use, resulting in reduced water catchment areas which is one of the factors causing inundation. Another factor causing inundation is surface runoff. In this study, surface runoff was measured to investigate the relationship between rainfall, surface runoff and water table. The research location was in Menteng IX road by constructing a $2 \times 10 \mathrm{~m}$ plot equipped with a plot boundary and a reservoir. Measurement of rainfall using a rain gauge, equipped with a rainwater basin. The water table were measured in monitoring wells using a ground water sensor. Land slope measurement using height difference method. The average surface runoff for 20 days is 0.0292 $\mathrm{mm}$. Rainfall has a significant relationship to surface runoff, the greater the rainfall that occurs, the greater surface runoff, indicated by an $\mathrm{R}^{2}$ of 0.92 . The relationship between surface runoff and groundwater level is the smaller the ground water level, the greater the surface runoff that occurs, indicated by an $\mathrm{R}^{2}$ of 0.85 .
\end{abstract}

Keywords: Surface Run Off, Rainfall, Water Table, Inundation

Abstrak: Jalan Temanggung Tilung merupakan salah satu jalan yang sering mengalami genangan. Perkembangan penduduk di kota Palangka Raya mengakibatkan meningkatnya kepadatan permukiman dan penggunaan lahan, sehingga berkurangnya daerah resapan air yang menjadi salah satu faktor terjadinya genangan. Faktor lainnya yang menyebabkan genangan adalah air larian atau air limpasan (surface run off) akibat curah hujan dan intensitas hujan yang melebihi laju infiltrasi air ke dalam tanah. Dalam penelitian ini dilakukan pengukuran air larian untuk melihat hubungan curah hujan, air larian dan muka air tanah. Lokasi penelitian berada di Jalan Menteng IX dengan membuat plot berukuran $2 \times 10 \mathrm{~m}$ yang dilengkapi dengan pembatas plot dan bak penampung. Pengukuran curah hujan menggunakan alat penakar curah hujan (rain bucket) yang dilengkapi bak penampung curah hujan. Muka air tanah diukur pada sumur pantau menggunakan alat sensor air tanah. Pengukuran kemiringan lahan menggunakan metode beda tinggi. Air larian rata-rata selama 20 hari kejadian adalah sebesar $0,0292 \mathrm{~mm}$. Curah hujan memiliki hubungan yang signifikan terhadap air larian, semakin besar curah hujan yang terjadi, maka semakin besar air larian, ditunjukkan dengan nilai $\mathrm{R}^{2}$ sebesar 0,92. Hubungan antara air larian dengan muka air tanah adalah semakin kecil muka air tanah, maka semakin besar air larian yang terjadi, ditunjukkan dengan nilai $\mathrm{R}^{2}$ sebesar 0,85 .

Kata kunci: : Air Larian, Curah Hujan, Muka Air Tanah, Genangan 


\section{PENDAHULUAN}

Kota Palangka Raya secara geografis terletak pada $113^{\circ} 30^{\prime}$ - $114^{\circ} 07^{\prime}$ Bujur Timur dan $1^{\circ} 35^{\prime}-2^{\circ} 24^{\prime}$ Lintang Selatan, dengan luas wilayah $2.399,50 \mathrm{Km}^{2}(239.950 \mathrm{Ha})$, kondisi topografi terdiri dari tanah datar dengan kemiringan $0 \%-8 \%$ dan bukit dengan kemiringan kurang dari 40\% (BPS Palangka Raya, 2018). Perkembangan penduduk di kota Palangka Raya mengakibatkan meningkatnya kepadatan permukiman dan penggunaan lahan, sehingga berkurangnya daerah resapan air yang menjadi salah satu faktor terjadinya genangan. Faktor lainnya yang menyebabkan genangan adalah air larian atau air limpasan (surface run off) akibat curah hujan dan intensitas hujan yang melebihi laju infiltrasi air ke dalam tanah.

Intensitas hujan akan mempengaruhi laju dan volume aliran permukaan. Pada hujan dengan intensitas tinggi, kapasitas infiltrasi akan terlampaui dengan beda yang cukup besar dibandingkan dengan hujan yang kurang intensif meskipun total curah hujan untuk kedua hujan tersebut sama besarnya. Namun demikian, hujan dengan intensitas tinggi dapat menurunkan infiltrasi akibat kerusakan struktur permukaan tanah yang ditimbulkan oleh hujan tersebut (Asdak, 1995).

Dari permasalahan dan latar belakang yang telah diuraikan tentang genangan yang sering terjadi di Kota Palangka Raya khususnya daerah Jalan Temanggung Tilung, maka penelitian ini bertujuan untuk : (1) mengetahui seberapa besar air larian yang terjadi; (2) mengetahui hubungan antara curah hujan dengan air larian; (3) mengetahui hubungan air larian dengan tinggi muka air tanah. Manfaat penelitian ini adalah sebagai informasi mengenai faktor yang berpengaruh terhadap genangan dengan mengetahui besar air larian yang terjadi.

\section{TINJAUAN PUSTAKA}

\section{Presipitasi}

Salah satu bentuk presipitasi yang terpenting di Indonesia adalah hujan. Hujan merupakan gejala meteorologi dan juga unsur klimatologi. Hujan adalah hydrometeor yang jatuh berupa partikel-partikel air yang mempunya diameter $0,5 \mathrm{~mm}$ atau lebih. Hydrometeor yang jatuh ke tanah disebut hujan sedangkan yang tidak sampai tanah disebut Vigra (Tjasyono, 2006).

Curah hujan merupakan salah satu unsur cuaca yang datanya diperoleh dengan cara mengukurnya dengan menggunakan alat penakar hujan, sehingga dapat diketahui jumlahnya dalam satuan milimeter ( $\mathrm{mm}$ ). Curah hujan $1 \mathrm{~mm}$ adalah jumlah air hujan yang jatuh di permukaan per satuan luas $\left(\mathrm{m}^{2}\right)$ dengan catatan tidak ada yang menguap, meresap atau mengalir. Jadi, curah hujan sebesar $1 \mathrm{~mm}$ setara dengan 1 liter $/ \mathrm{m}^{2}$ (Aldrian dkk. 2011).

Intensitas curah hujan adalah jumlah curah hujan yang dinyatakan dalam tinggi hujan atau volume hujan tiap satuan waktu, yang terjadi pada satu kurun waktu air hujan terkonsentrasi (Wesli, 2008).

Penakar hujan adalah instrumen yang digunakan untuk mendapatkan dan mengukur jumlah curah hujan pada satuan waktu tertentu. Penakar hujan mengukur tinggi hujan seolaholah air hujan yang jatuh ke tanah menumpuk ke atas merupakan kolom air. Air yang tertampung volumenya dibagi dengan luas corong penampang, hasilnya adalah tinggi atau tebal, satuan yang dipakai adalah milimeter (Manullang, 2013)

Secara umum alat penakar hujan terbagi dalam 3 jenis yaitu (Manullang, 2013).

1. Jenis penakar hujan biasa tipe Obervatorium (Obs) atau konvensional.

2. Jenis penakar hujan mekanik recorder (Jenis Hellman)

3. Jenis penakar hujan otomatis/penakar hujan tipping bucket.

Menentukan lokasi alat penakar presipitasi harus mampu mewakili daerah yang akan diamati dan dapat dipantau secara teratur untuk mengetahui apakah ada perubahan yang terjadi pada alat penakar atau ada hal lain yang mengganggu.

Berikut adalah persamaan yang digunakan untuk perhitungan curah hujan dan intensitas hujan menurut Ziliwu (2002) :

1. Perhitungan curah hujan :

$$
C H=\frac{V}{A} \times 10
$$

Keterangan rumus :

$\mathrm{CH}$ : curah hujan (mm)

$V$ : volume air hujan yang tertampung (ml)

$A$ : luas permukaan penakar hujan $\left(\mathrm{cm}^{2}\right)$ 
2. Perhitungan intensitas hujan :

$$
\begin{aligned}
& I=\frac{C H}{t} \\
& \text { Keterangan rumus : } \\
& I \quad: \text { intensitas hujan }(\mathrm{mm} / \mathrm{jam}) \\
& \mathrm{CH}: \text { : curah hujan harian }(\mathrm{mm}) \\
& t \quad: \text { durasi hujan }(\mathrm{jam})
\end{aligned}
$$

\section{Air Larian atau Limpasan Permukaan}

Limpasan permukaan atau aliran permukaan merupakan sebagian dari air hujan yang mengalir di atas permukaan tanah. Jumlah air yang menjadi limpasan sangat bergantung kepada jumlah air hujan persatuan waktu, keadaan penutup tanah, topografi (terutama kemiringan lahan), jenis tanah, dan ada atau tidaknya hujan yang terjadi sebelumnya. Limpasan permukaan dengan jumlah dan kecepatan yang besar sering menyebabkan pemindahan atau pengangkutan massa tanah secara besar-besaran (Rahim, 2000).

Ketika air hujan jatuh ke permukaan tanah sejumlah air yang jatuh akan terinfiltrasi ke dalam tanah, sebagian tersimpan di permukaan sampai akhirnya akan meresap ke dalam tanah. Perencanaan pembuatan drainase di permukaan tanah, struktur penanganan air dan air yang tersimpan akan mempengaruhi jumlah dan laju aliran air permukaan (Schwab et al. 1982).

Perkiraan air larian terdapat dua cara, yaitu cara pendekatan persamaan empiris dan cara langsung. Perkiraan dengan pendekatan empiris umumnya dilakukan untuk penulisan laporan-laporan teknis tentang hidrologi atau perencanaan sumber daya air. Kekurangannya adalah karena perhitungan air larian tersebut dilakukan dengan menggunakan persamaan empiris, maka tingkat akurasi hasil perhitungan juga tidak sebaik apabila perhitungan air larian dilakukan dengan cara pengukuran langsung di lapangan (Asdak, 2010).

Pengukuran besarnya air larian di lapangan biasanya dilakukan dengan membuat plot pengukuran air larian. Ukuran plot air larian umumnya bervariasi tergantung pada bentuk dan besaran treatment serta luas wilayah yang akan menjadi kajian. Plot dengan ukuran lebar $2 \mathrm{~m}$ dan panjang antara 42 - $86 \mathrm{~m}$ sering digunakan untuk penelitian-penelitian air larian untuk mengukur besarnya transpor sedimen (Ebisemiju, 1990). Plot air larian dan erosi yang lebih sederhana dibuat oleh USDA (United
States Department of Agriculture) (Wischmeier dan Scmith, 1978) dengan ukuran 4 x $22 \mathrm{~m}$. Sinun et al. (1992), mengukur besarnya air larian di hutan hujan tropis yang bentuk perlakuannya adalah dengan menghilangkan tumbuhan bawah dan penutupan tanah lainnya dengan menggunakan plot yang berukuran $2 \mathrm{x}$ $10 \mathrm{~m}$, yang diperkirakan akan meningkatkan edge effect yang disebabkan oleh vegetasi di sekitar batas plot.

Berikut adalah persamaan yang digunakan untuk perhitungan volume dan besaran air larian :

1. Perhitungan volume air larian dapat dihitung dengan persamaan berikut (Van, 1953) :

a. Apabila penampung berbentuk kerucut terpancung :

$\mathrm{V}_{\text {kerucut terpancung }}=$

$\frac{1}{3} \times \pi \times H\left(R^{2}+R r+r^{2}\right)$

b. Apabila penampung berbentuk silinder :

$\mathrm{V}_{\text {silinder }}=\pi \times r^{2} \times H$

Keterangan rumus :

$V$ : volume air larian $\left(1 \mathrm{ml}=1 \mathrm{~cm}^{3}\right)$

$H$ : tinggi permukaan air $(\mathrm{cm})$

$R:$ jari-jari permukaan air bak kerucut (cm)

$r:$ jari-jari alas bak kerucut $(\mathrm{cm})$

$r$ : jari-jari bak silinder $(\mathrm{cm})$

2. Perhitungan besarnya air larian dapat dihitung dengan persamaan berikut (Ziliwu, 2002) :

$$
\text { Ro }=\frac{V}{A}
$$

Keterangan rumus :

Ro : runoff (mm)

$V$ : volume air larian $(\mathrm{ml})$

$A$ : luas permukaan plot $\left(\mathrm{m}^{2}\right)$

\section{Topografi}

Topografi berperan dalam menentukan kecepatan dan volume air larian. Kemiringan dan panjang lereng adalah dua sifat topografi yang paling berpengaruh terhadap aliran permukaan dan erosi (Arsyad, 2010).

Kemiringan lereng memperbesar jumlah aliran permukaan, semakin curam lereng juga memperbesar kecepatan aliran permukaan yang dengan demikian memperbesar energi angkut aliran permukaan. Jika lereng permukaan tanah menjadi dua kali lebih curam, maka banyaknya erosi per satuan luas menjadi 2,0 sampai 2,5 
kali lebih besar. Erosi semakin besar dengan semakin curam lereng. Sementara besarnya erosi menjadi lebih dari dua kali lebih besar dengan lereng menjadi dua kali lebih curam jumlah aliran permukaan tidak banyak bertambah bahkan cenderung mendatar. Hal ini disebabkan, karena jumlah aliran permukaan dibatasi oleh jumlah air yang jatuh (Arsyad, 2010).

Tabel 1. Kelas kemiringan lereng dan nilai skor kemiringan lereng

\begin{tabular}{|c|c|c|}
\hline Kelas & Kemiringan (\%) & Klasifikasi \\
\hline I & $0-8$ & Datar \\
\hline II & $>8-15$ & Landai \\
\hline III & $>15-25$ & Agak Curam \\
\hline IV & $>25-45$ & Curam \\
\hline V & $>45$ & Sangat Curam \\
\hline
\end{tabular}

Sumber : Pedoman Penyusunan Pola Rehabilitasi Lahan dan Konservasi Tanah, 1986

Berikut adalah persamaan yang digunakan untuk menghitung kemiringan lahan (Hidayat, 2001) :

Kemiringan slope :

$$
S=\frac{\Delta h}{D} \times 100 \%
$$

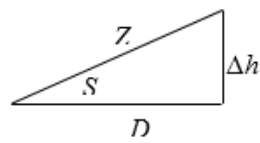

Keterangan rumus :

$$
\begin{array}{ll}
S & : \text { kemiringan lahan }(\%) \\
D & : \text { jarak antar titik }(\mathrm{m}) \\
\Delta h & : \text { beda tinggi }(\mathrm{m}) \\
Z & : \text { panjang lereng }(\mathrm{m})
\end{array}
$$

\section{Air Tanah}

Air yang berada di wilayah jenuh permukaan tanah disebut air tanah. Tinggi muka air tanah tidak bersifat statis, melainkan berfluktuasi naik turun tergantung pada fluktuasi curah hujan (Asdak, 1995).

Air tanah merupakan salah satu bagian/unsur dalam siklus hidrologi. Dengan membuat/menggali lubang (sumur) untuk kemudian mengamati air tanah dalam sumur itu, baik dengan metode elektrik, maupun metode sonik (kecepatan bunyi) (Martha dan Adidarma, 1982).
Lubang tanah yang dibuat untuk mengamati air tanah ada 3 jenis yaitu (Asdak, 2010) :

1. Piezometer

Terdiri dari pipa/casing bambu atau PVC yang dilubangi bagian ujung bawahnya, kemudian dimasukkan ke dalam lubang bor sampai menembus formasi geologi yang hendak diamati muka airnya.

2. Sumur pengamat (Observation well)

Terdiri dari pipa/casing yang dindingnya digergaji atau dilubangi dan langsung dimasukkan lubang bor tanpa dinding pengikat, tidak menembus lapisan kedap air, karena sumur ini berfungsi sebagai tempat pengamatan muka air bebas.

3. Sumur produksi (Production well)

Sumur produksi dapat berfungsi sebagai sumur pengamat bagi air dari lapisan pembawa air yang tertekan.

Alat pengukuran muka air secara manual yang umum dipakai adalah dengan menggantungkan kabel berikut pemberat dalam sumur, dilengkapi dengan atau tanpa peralatan elektrik untuk mengeluarkan suara atau nyala lampu pada waktu pemberat mencapai muka air.

Perhitungan tinggi muka air tanah sebagai berikut :

Tinggi Muka Air Tanah $(\Delta h)=h_{1}-h_{2}$

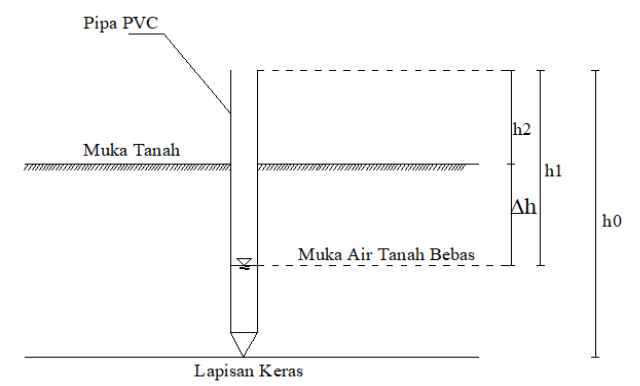

Gambar 1. Sketsa pengukuran tinggi muka air tanah

Keterangan rumus :

$\Delta h$ : beda tinggi muka air tanah dengan muka tanah $(\mathrm{cm})$

$h_{1}$ : beda tinggi muka air tanah dengan muka pipa $(\mathrm{cm})$

$h_{2}$ : beda tinggi muka tanah dengan muka pipa (cm) 


\section{METODE PENELITIAN}

\section{Lokasi dan Waktu Penelitian}

Lokasi penelitian berada di Jalan Menteng IX, kawasan Jalan Temanggung Tilung, Kota Palangka Raya, Kalimantan Tengah. Dengan menggunakan lahan berukuran 25 x $40 \mathrm{~m}$, dengan kondisi ditumbuhi tanaman ilalang dan paku-pakuan yang kemudian dibersihkan untuk memudahkan pengukuran. Koordinat lokasi berada pada $2^{\circ} 14^{\prime} 19,87141^{\prime \prime L S}$ dan 1135'ㄹ, 16926"BT . Waktu penelitian selama 6 (enam) bulan, dimulai dari bulan Juni hingga November 2019. Pengukuran dilakukan pada pagi hari pukul 07.00 WIB setelah kejadian hujan.

\section{Tahapan Penelitian}

Tahapan penelitian dilakukan dalam lima tahap, setiap tahapan penelitian saling berhubungan satu sama lain, berikut adalah tahapan penelitian :

1. Tahap pendahuluan penelitian yang meliputi penyusunan latar belakang, rumusan masalah, batasan masalah, tujuan dan manfaat pada penelitian.

2. Tahap studi literatur penelitian yang mencakup literatur-literatur yang terkait dengan penelitian yang dilakukan.

3. Tahap pengumpulan data penelitian yang digunakan dalam penelitian yang dilakukan yang meliputi proses observasi, dan pengukuran langsung di lapangan.

4. Tahap analisis data penelitian, tahapan ini mencakup pengolahan data untuk dilanjutkan ke proses analisis data.

5. Tahap penutup, tahapan ini adalah penarikan kesimpulan dan saran terhadap hasil penelitian.

\section{Metode Pengumpulan Data}

Metode pengumpulan data yang dilakukan adalah metode observasi dan pengukuran langsung di lapangan dengan tahapan sebagai berikut :

1. Pemasangan alat rain bucket dan pipa pantau muka air tanah dilakukan pada hari Kamis tanggal 20 Juni 2019 untuk memperoleh data yang berkesinambungan.

a) Pencatatan curah hujan dilakukan satu hari setelah terjadi hujan dan dilakukan pada pukul 07.00 pagi sehingga diperoleh akumulasi curah hujan dalam satu hari (mm/hari) b) Pencatatan tinggi muka air tanah menggunakan alat sensor air tanah yang dimasukkan ke dalam sumur pengamat terbuat dari pipa PVC berlubang sisinya yang telah tertanam ke tanah tanpa menembus lapisan kedap air. Pengukuran dilakukan sehari setelah hujan dan minimal dua kali seminggu apabila tidak terjadi hujan.

2. Pengukuran kemiringan lahan dengan metode sederhana menggunakan selang transparan yang berisi air, kemudian kedua ujung selang diikat pada dua buah patok yang dipasang pada jarak yang telah ditentukan. Beda tinggi kedua air pada selang diukur kemudian dibagi dengan jarak kedua patok dan dikalikan 100\%, sehingga didapatkan persentase kemiringan lahan.

3. Data air larian didapatkan dengan membuat plot lahan berukuran $2 \times 10 \mathrm{~m}$ mengacu pada Handbook for Agrohydrology (Miller, S, 1994) yang menyatakan dimensi plot harus sesuai dengan estimasi run off yang diperkirakan, ukuran plot $10 \mathrm{~m}^{2}$ sampai 100 $\mathrm{m}^{2}$. Sinun et al (1992) mengukur air larian di hutan hujan tropis dengan perlakuan menghilangkan tumbuhan penutup tanah, ukuran plot yang digunakan $2 \times 10 \mathrm{~m}$.

\section{Teknik Analisis Data}

dilakukan :

Berikut adalah analisis data yang

1. Perhitungan kemiringan lahan dapat dilakukan dengan persamaan (6)

2. Perhitungan curah hujan dapat dilakukan dengan persamaan (1)

3. Perhitungan curah hujan dapat dilakukan dengan persamaan (2)

4. Perhitungan volume air larian dapat dilakukan dengan persamaan (3) dan (4) yang kemudian hasilnya diakumulasikan dan dimasukkan ke dalam persamaan (5) sehingga didapatkan volume air larian dalam skala luasan plot yang direncanakan.

5. Perhitungan tinggi muka air tanah dapat dilakukan dengan persamaan (7)

6. Seluruh data hasil analisis dikumpulkan dan diketahui hubungannya (grafik).

a. Hubungan curah hujan $(\mathrm{mm})$ dengan air larian $(\mathrm{mm})$

b. Hubungan air larian dengan tinggi muka air tanah. 


\section{HASIL PENELITIAN}

\section{Kemiringan Lahan}

Hasil pengukuran kemiringan lahan dapat dilihat pada Tabel 2 berikut :

Tabel 2. Perhitungan kemiringan lahan

\begin{tabular}{cccc}
\hline \multicolumn{1}{c}{ No. } & Beda Tinggi $\mathbf{( c m )}$ & Jarak $(\mathbf{c m})$ & $\begin{array}{c}\text { Kemiringan } \\
(\boldsymbol{\%})\end{array}$ \\
\hline 1 dan 2 & 2,8 & 200 & 1,4 \\
2 dan 3 & 6,7 & 200 & 3,35 \\
3 dan 4 & 6 & 200 & 3 \\
4 dan 5 & 14,8 & 200 & 7,4 \\
5 dan 6 & 14,7 & 200 & 7,35 \\
6 dan 7 & 2,3 & 200 & 1,15 \\
7 dan 8 & 8,6 & 200 & 4,3 \\
8 dan 9 & 3,5 & 200 & 1,75 \\
9 dan 10 & 2,6 & 200 & 1,3 \\
10 dan 11 & 1,2 & 200 & 0,6 \\
11 dan 12 & 2,3 & 200 & 1,15 \\
1 dan 12 & 6,3 & 200 & 3,15 \\
2 dan 11 & 6,8 & 200 & 3,4 \\
3 dan 10 & 1,1 & 200 & 0,55 \\
4 dan 9 & 7,5 & 200 & 3,75 \\
5 dan 8 & 3,8 & 200 & 1,9 \\
1 dan 11 & 4 & 282,843 & 1,41 \\
2 dan 12 & 9,1 & 282,843 & 3,22 \\
2 dan 10 & 5,6 & 282,843 & 1,98 \\
3 dan 9 & 1,5 & 282,843 & 0,53 \\
4 dan 10 & 4,9 & 282,843 & 1,73 \\
4 dan 8 & 11 & 282,843 & 3,89 \\
5 dan 9 & 7,3 & 282,843 & 2,58 \\
5 dan 7 & 12,4 & 282,843 & 4,38 \\
6 dan 8 & 10,9 & 282,843 & 3,85 \\
\hline & Rata- rata & & 2,76 \\
\hline
\end{tabular}

Sumber : Hasil Perhitungan

Dari hasil pengukuran elevasi tersebut dapat ditentukan lokasi dan jumlah bak penampung. Sketsa plot setelah dilakukan pengukuran elevasi dan kemiringan dapat dilihat pada gambar berikut :

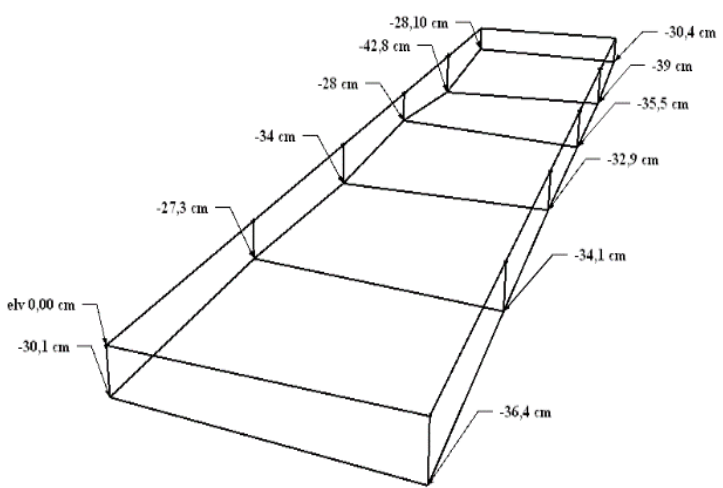

Gambar 2. Sketsa elevasi lahan plot air larian

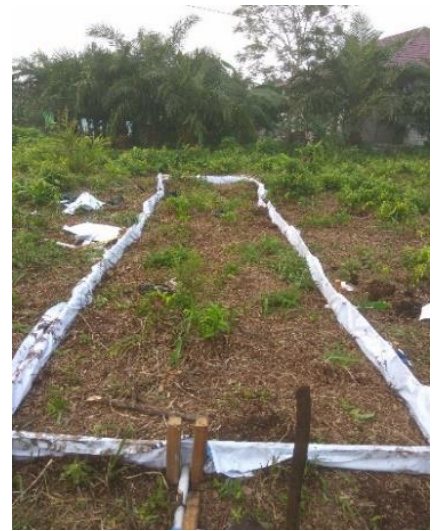

Gambar 3. Plot air larian

\section{Pengukuran Curah Hujan dan Intensitas Hujan}

Hasil pengukuran curah hujan dan intensitas hujan selama 20 hari kejadian hujan dapat dilihat pada Tabel 3 berikut :

Tabel 3. Pengukuran curah hujan dan intensitas hujan

\begin{tabular}{|c|c|c|c|c|c|}
\hline \multirow{2}{*}{ No } & \multicolumn{3}{|c|}{ Waktu } & \multirow{2}{*}{$\begin{array}{l}\text { Curah } \\
\text { Hujan } \\
(\mathbf{m m})\end{array}$} & \multirow{2}{*}{$\begin{array}{c}\text { Inten } \\
\text { sitas } \\
\text { Hujan } \\
\text { (mm/ } / \text { jam) }\end{array}$} \\
\hline & $\begin{array}{l}\text { Tanggal } \\
\text { hujan }\end{array}$ & $\begin{array}{l}\text { Durasi } \\
\text { Hujan }\end{array}$ & $\begin{array}{c}\text { Waktu } \\
\text { Pengamatan }\end{array}$ & & \\
\hline 1 & 20-sep-19 & 1,00 & $07.00 \mathrm{WIB}$ & 6,37 & 6,37 \\
\hline 2 & 23-Sep-19 & 0,33 & 07.00 WIB & 4,77 & 14,32 \\
\hline 3 & 24-Sep-19 & 0,67 & $07.00 \mathrm{WIB}$ & 2,86 & 4,30 \\
\hline 4 & 25-Sep-19 & 0,33 & 07.00 WIB & 0,16 & 0,48 \\
\hline 5 & 29-Sep-19 & 0,67 & 05.40 WIB & 8,59 & 12,89 \\
\hline 6 & $30-$ Sep-19 & 0,75 & 05.30 WIB & 19,42 & 25,89 \\
\hline 7 & 2-Oct-19 & 0,75 & 05.30 WIB & 22,28 & 29,71 \\
\hline 8 & 4-Oct-19 & 0,17 & 05.30 WIB & 0,95 & 5,73 \\
\hline 9 & 6-Oct-19 & 3,47 & 05.30 WIB & 123,50 & 35,63 \\
\hline 10 & $10-$ Oct-19 & 0,17 & 05.30 WIB & 0,32 & 1,91 \\
\hline 11 & 11 -Oct-19 & 0,33 & 05.30 WIB & 0,16 & 0,48 \\
\hline 12 & 13-Oct-19 & 0,50 & 07.00 WIB & 0,16 & 0,32 \\
\hline 13 & 15 -Oct-19 & 1,92 & 06.30 WIB & 14,01 & 7,31 \\
\hline 14 & 17-Oct-19 & 0,42 & 06.00 WIB & 10,19 & 24,45 \\
\hline 15 & 18-OCt-19 & 0,42 & 05.30 WIB & 2,23 & 5,35 \\
\hline 16 & 19-Oct-19 & 0,17 & 05.30 WIB & 0,32 & 1,91 \\
\hline 17 & 25-Oct-19 & 1,75 & 06.00 WIB & 8,28 & 4,73 \\
\hline 18 & 31-Oct-19 & 0,42 & $06.30 \mathrm{WIB}$ & 0,32 & 0,76 \\
\hline 19 & 1-Nov-19 & 2 & 06.30 WIB & 11,14 & 5,57 \\
\hline 20 & 13-Nov-19 & 0,6 & 06.00 WIB & 10,50 & 17,51 \\
\hline
\end{tabular}

Berdasarkan Tabel 3, hujan terbesar terjadi pada tanggal 06 Oktober 2019 dengan curah hujan dan intensitas hujan berturut-turut sebesar 123,50 mm dan 35,64 mm/jam dengan durasi hujan selama 3 jam 28 menit.

Berikut contoh perhitungan curah hujan dan intensitas hujan :

$$
\begin{aligned}
C H & =\frac{V}{A} \times 10 \\
& =\frac{3.880 \mathrm{~cm}^{3}}{314,16 \mathrm{~cm}^{2}} \times 10 \\
& =123,50 \mathrm{~mm}(\text { contoh perhitungan No. 9) }
\end{aligned}
$$


Keterangan :

$\mathrm{CH}$ : curah hujan

$V \quad$ : volume air tertampung $\left(1 \mathrm{ml}=1 \mathrm{~cm}^{3}\right)$

$A$ : luas permukaan penakar hujan (rain bucket)

$$
\begin{aligned}
\mathrm{d} & =20 \mathrm{~cm} \\
& =\pi \times \mathrm{r}^{2} \\
& =\pi \times 102 \\
& =314,16 \mathrm{~cm}^{2}
\end{aligned}
$$

$I=\frac{C H}{t}$

$$
=\frac{123,50}{3,47}
$$

$=35,63 \mathrm{~mm} / \mathrm{jam}$ (contoh perhitungan No.9)

Keterangan :

$I \quad:$ Intensitas hujan ( $\mathrm{mm} / \mathrm{jam})$

$\mathrm{CH}$ : curah hujan harian $(\mathrm{mm})$

$t$ : durasi hujan (jam)

\begin{tabular}{|c|c|c|c|c|c|}
\hline \multirow{2}{*}{ No. } & \multicolumn{2}{|c|}{ Waktu Pengukuran } & \multirow{2}{*}{$\begin{array}{c}\text { Tinggi } \\
\text { Pipa- } \\
\text { Muka } \\
\text { Tanah } \\
\text { (cm) }\end{array}$} & \multirow{2}{*}{$\begin{array}{c}\text { Tinggi } \\
\text { Pipa- } \\
\text { Air } \\
(\mathbf{c m})\end{array}$} & \multirow{2}{*}{$\begin{array}{c}\text { Tinggi } \\
\text { Muka } \\
\text { Air } \\
\text { Tanah } \\
\text { Muka } \\
\text { Tanah } \\
\text { (cm) }\end{array}$} \\
\hline & Tanggal & Pukul & & & \\
\hline 1 & 21-Sep-19 & $07.00 \mathrm{WIB}$ & 126,23 & 185,50 & 59,27 \\
\hline 2 & 23-Sep-19 & $07.00 \mathrm{WIB}$ & 126,47 & 186,80 & 60,33 \\
\hline 3 & 24-Sep-19 & $07.00 \mathrm{WIB}$ & 126,47 & 183,20 & 56,73 \\
\hline 4 & 25-Sep-19 & $07.00 \mathrm{WIB}$ & 126,47 & 185,80 & 59,33 \\
\hline 5 & 26-Sep-19 & $07.00 \mathrm{WIB}$ & 126,47 & 186,20 & 59,73 \\
\hline 6 & 30-Sep-19 & $05.30 \mathrm{WIB}$ & 126,40 & 185,00 & 58,60 \\
\hline 7 & $1-$ Oct-19 & $05.30 \mathrm{WIB}$ & 126,40 & 177,80 & 51,40 \\
\hline 8 & 3 -Oct-19 & $05.30 \mathrm{WIB}$ & 126,33 & 162,00 & 35,67 \\
\hline 9 & $5-O c t-19$ & $05.30 \mathrm{WIB}$ & 126,33 & 163,70 & 37,37 \\
\hline 10 & 7-Oct-19 & $05.30 \mathrm{WIB}$ & 126,40 & 134,50 & 8,10 \\
\hline 11 & $10-$ Oct-19 & $05.30 \mathrm{WIB}$ & 126,20 & 147,80 & 21,60 \\
\hline 12 & 11-Oct-19 & $05.30 \mathrm{WIB}$ & 126,20 & 149,70 & 23,50 \\
\hline 13 & 12-Oct-19 & $07.00 \mathrm{WIB}$ & 126,40 & 151,40 & 25,00 \\
\hline 14 & $14-$ Oct- 19 & $07.00 \mathrm{WIB}$ & 126,20 & 154,00 & 27,80 \\
\hline
\end{tabular}

\section{Pengukuran Tinggi Muka Air Tanah}

Hasil pengukuran tinggi muka air tanah

\begin{tabular}{|c|c|c|c|c|c|}
\hline 15 & 16-Oct-19 & $06.30 \mathrm{WIB}$ & 126,30 & 153,40 & 27,10 \\
\hline 16 & 19-Oct-19 & $06.00 \mathrm{WIB}$ & 126,27 & 150,50 & 24,23 \\
\hline 17 & $20-$ Oct- 19 & $05.30 \mathrm{WIB}$ & 126,23 & 151,00 & 24,77 \\
\hline 18 & 24-Oct-19 & $06.30 \mathrm{WIB}$ & 126,27 & 152,70 & 26,43 \\
\hline 19 & 26-Oct-19 & $06.30 \mathrm{WIB}$ & 126,33 & 160,50 & 34,17 \\
\hline 20 & 26-Oct-19 & $06.00 \mathrm{WIB}$ & 126,30 & 159,70 & 33,40 \\
\hline 21 & 31-Oct-19 & $05.30 \mathrm{WIB}$ & 126,23 & 165,00 & 38,77 \\
\hline 22 & 1-Nov-19 & $06.20 \mathrm{WIB}$ & 126,43 & 165,70 & 39,27 \\
\hline 23 & 2-Nov-19 & $06.40 \mathrm{WIB}$ & 126,43 & 162,00 & 35,57 \\
\hline 24 & 5-Nov-19 & $05.20 \mathrm{WIB}$ & 126,43 & 165,00 & 38,57 \\
\hline 25 & 10-Nov-19 & $06.00 \mathrm{WIB}$ & 126,40 & 171,60 & 45,20 \\
\hline 26 & 14-Nov-19 & $06.00 \mathrm{WIB}$ & 126,37 & 171,90 & 45,53 \\
\hline
\end{tabular}
dapat dilihat pada Tabel 4 berikut :

Tabel 4. Pengukuran tinggi muka air tanah
Tabel 4. Lanjutan

Sumber : Hasil Perhitungan

Berdasarkan Tabel 4, tinggi muka air tanah bervariasi. Muka air tanah tertinggi terjadi tanggal 7 Oktober 2019 yang hanya berjarak $8,10 \mathrm{~cm}$ dari muka tanah.

\section{Pengukuran Air Larian}

Pengukuran air larian dilakukan satu hari setelah kejadian hujan, dengan cara mengakumulasi air yang tertampung dalam 6 buah bak tampungan dan dibagi dengan luas plot air larian. Berikut adalah contoh perhitungan air larian :

$$
\begin{aligned}
R o & =\frac{V_{b a k 1+b a k 2+b a k 3+b a k 4+b a k 5+b a k 6}}{A} \times 10 \\
& =\frac{0+0+40+0+0+0 \mathrm{~cm}^{3}}{200.000 \mathrm{~cm}^{2}} \times 10 \\
& =0,002 \mathrm{~mm} \text { (contoh perhitungan No.2) }
\end{aligned}
$$

Keterangan :

Ro : air larian (mm)

$V$ : volume air tampungan di bak air larian

\begin{tabular}{|c|c|c|c|c|c|c|c|c|c|c|}
\hline \multirow{2}{*}{$\begin{array}{l}\text { No. } \\
\text { (1) }\end{array}$} & \multirow{2}{*}{$\begin{array}{c}\text { Tanggal } \\
\text { Hujan } \\
\text { (2) }\end{array}$} & \multirow{2}{*}{$\begin{array}{c}\text { Curah } \\
\text { Hujan } \\
\text { (mm) } \\
\text { (3) }\end{array}$} & \multicolumn{6}{|c|}{ Tampungan (ml) } & \multicolumn{2}{|c|}{ Air Larian } \\
\hline & & & $\begin{array}{c}\text { Bak } 1 \\
(4)\end{array}$ & $\begin{array}{c}\text { Bak } 2 \\
(5)\end{array}$ & $\begin{array}{c}\text { Bak } 3 \\
(6)\end{array}$ & $\begin{array}{c}\text { Bak } 4 \\
(7)\end{array}$ & $\begin{array}{c}\text { Bak } 5 \\
(8)\end{array}$ & $\begin{array}{c}\text { Bak 6 } \\
(9)\end{array}$ & $\begin{array}{l}\mathrm{mm} \\
(\mathbf{1 0})\end{array}$ & $\begin{array}{c}\% \\
\text { (11) }\end{array}$ \\
\hline 1 & 20-Sep-19 & 6,37 & 0,00 & 0,00 & 0,00 & 0,00 & 0,00 & 0,00 & 0,000 & 0 \\
\hline 2 & 23-Sep-19 & 4,77 & 0,00 & 0,00 & 40,00 & 0,00 & 0,00 & 0,00 & 0,002 & 0,04 \\
\hline 3 & 24-Sep-19 & 2,86 & 0,00 & 0,00 & 0,00 & 0,00 & 0,00 & 0,00 & 0,000 & 0 \\
\hline 4 & 25-Sep-19 & 0,16 & 0,00 & 0,00 & 0,00 & 0,00 & 0,00 & 0,00 & 0,000 & 0 \\
\hline 5 & 29-Sep-19 & 8,59 & 60,00 & 80,00 & 0,00 & 10,00 & 0,00 & 350,00 & 0,025 & 0,29 \\
\hline 6 & 30-Sep-19 & 19,42 & 0,50 & 500,00 & 80,00 & 40,00 & 0,00 & 790,00 & 0,071 & 0,36 \\
\hline
\end{tabular}

$$
\left(1 \mathrm{ml}=1 \mathrm{~cm}^{3}\right)
$$

$A$ : luas permukaan plot $\left(\mathrm{cm}^{2}\right)$

$$
=200 \mathrm{~cm} \mathrm{x} 1.000 \mathrm{~cm}=20.000 \mathrm{~cm}^{2}
$$

Air larian rata-rata selama 20 hari kejadian hujan :

Rata - rata $=\frac{0,583}{20}=0,0292 \mathrm{~mm}$

Tabel 5. Pengukuran air larian 
Tabel 5. Lanjutan

\begin{tabular}{|c|c|c|c|c|c|c|c|c|c|c|}
\hline \multirow{2}{*}{$\begin{array}{l}\text { No. } \\
\text { (1) }\end{array}$} & \multirow{2}{*}{$\begin{array}{l}\text { Tanggal } \\
\text { Hujan } \\
\text { (2) }\end{array}$} & \multirow{2}{*}{$\begin{array}{c}\text { Curah } \\
\text { Hujan } \\
\text { (mm) } \\
(3)\end{array}$} & \multicolumn{6}{|c|}{ Tampungan (ml) } & \multicolumn{2}{|c|}{ Air Larian } \\
\hline & & & $\begin{array}{c}\text { Bak 1 } \\
\text { (4) }\end{array}$ & $\begin{array}{c}\text { Bak 2 } \\
\text { (5) }\end{array}$ & $\begin{array}{c}\text { Bak 3 } \\
\text { (6) }\end{array}$ & $\begin{array}{c}\text { Bak } 4 \\
(7)\end{array}$ & $\begin{array}{c}\text { Bak 5 } \\
\text { (8) }\end{array}$ & $\begin{array}{c}\text { Bak 6 } \\
(9)\end{array}$ & $\begin{array}{l}\mathbf{m m} \\
(\mathbf{1 0})\end{array}$ & $\begin{array}{c}\% \\
(11)\end{array}$ \\
\hline 7 & 2-Oct-19 & 22,28 & 120,00 & 480,00 & 80,00 & 30,00 & 0,00 & $1.450,00$ & 0,108 & 0,48 \\
\hline 8 & 4-Oct-19 & 0,95 & 0,00 & 0,00 & 0,00 & 0,00 & 0,00 & 0,00 & 0,000 & 0 \\
\hline 9 & 6-Oct-19 & 123,50 & 30,00 & Genangan & Genangan & $2.740,00$ & Genangan & $2.660,00$ & 0,272 & 0,22 \\
\hline 10 & 10-Oct-19 & 0,32 & 0,00 & 0,00 & 0,00 & 0,00 & 0,00 & 0,00 & 0,000 & 0 \\
\hline 11 & 11-Oct-19 & 0,16 & 0,00 & 0,00 & 0,00 & 0,00 & 0,00 & 0,00 & 0,000 & 0 \\
\hline 12 & 13-OCt-19 & 0,16 & 0,00 & 0,00 & 0,00 & 0,00 & 0,00 & 0,00 & 0,000 & 0 \\
\hline 13 & $15-$-Oct-19 & 14,01 & 30,00 & 0,00 & 10,00 & 0,00 & 0,00 & 120,00 & 0,008 & 0,06 \\
\hline 14 & 17-Oct-19 & 10,19 & 130,00 & 110,00 & 0,00 & 0,00 & 0,00 & 20,00 & 0,013 & 0,13 \\
\hline 15 & 18-Oct-19 & 2,23 & 0,00 & 0,00 & 0,00 & 0,00 & 0,00 & 0,00 & 0,000 & 0 \\
\hline 16 & 19-Oct-19 & 0,32 & 0,00 & 0,00 & 0,00 & 0,00 & 0,00 & 0,00 & 0,000 & 0 \\
\hline 17 & 25-Oct-19 & 8,28 & 390,00 & 120,00 & 0,00 & 200,00 & 0,00 & 10,00 & 0,036 & 0,43 \\
\hline 18 & 31-Oct-19 & 0,32 & 0,00 & 0,00 & 0,00 & 0,00 & 0,00 & 0,00 & 0,000 & 0 \\
\hline 19 & 1-Nov-19 & 11,14 & 210,00 & 120,00 & 0,50 & 40,00 & 0,00 & 130,00 & 0,025 & 0,22 \\
\hline 20 & 13-Nov-19 & 10,50 & 0,00 & 90,00 & 50,00 & 210,00 & 70,00 & 60,00 & 0,024 & 0,23 \\
\hline
\end{tabular}

Sumber : Hasil Perhitungan

Keterangan tabel :

$(11)=\frac{(10)}{(3)} \times 100 \%$

\section{Hubungan Curah Hujan dengan Air Larian}

Hasil hubungan antara curah hujan dan air larian dapat dilihat pada Gambar 4 berikut :

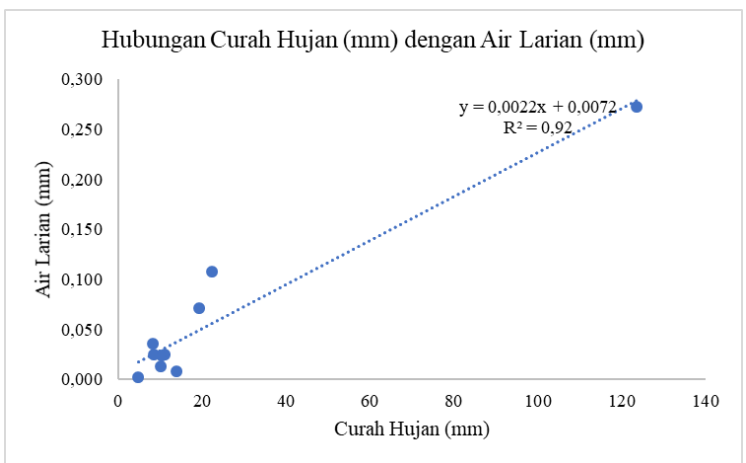

Gambar 4. Hubungan curah hujan dan air larian

Dari Gambar 4 menunjukkan semakin besar curah hujan yang terjadi, maka semakin besar air larian, yang artinya adalah curah hujan memiliki hubungan yang signifikan terhadap air larian. Hal ini ditunjukkan dari nilai $\mathrm{R}^{2}=0,92$. Dalam rentang waktu pengamatan, nilai curah hujan tidak sama dengan 0 , yang berarti data yang digunakan hanya saat terjadi hujan dan air larian.

\section{Hubungan Air Larian dengan Tinggi Muka Air Tanah}

Diagram antara air larian dengan tinggi muka air tanah dengan muka tanah dapat dilihat pada Gambar 5 sebagai berikut :

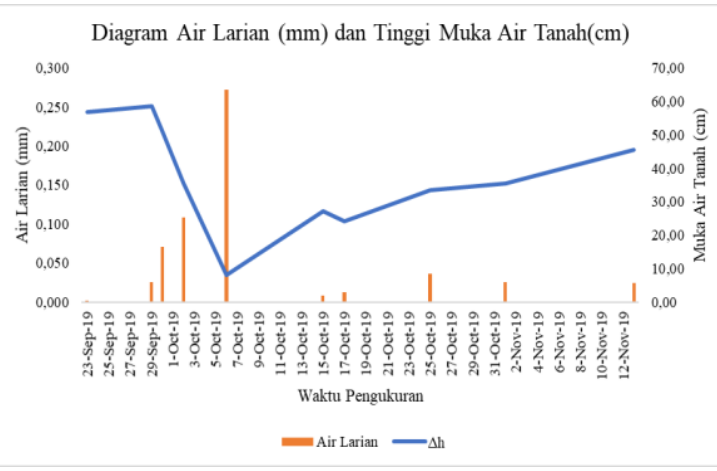

Gambar 5. Diagram air larian dan tinggi muka air tanah

Berdasarkan Gambar 5, diketahui bahwa semakin kecil muka air tanah maka semakin besar air larian yang terjadi. Pada kejadian hujan tanggal 06 Oktober, didapatkan hasil pengukuran muka air tanah sebesar $8,10 \mathrm{~cm}$ dan air larian sebesar 0,272 mm. Karena kejadian hujan yang tidak beraturan sehingga menyebabkan fluktuasi data pengukuran yang cukup besar, terlihat dari beberapa data yang kosong.

Untuk grafik hubungan antara air larian dan muka air tanah dapat dilihat pada Gambar 6 berikut :

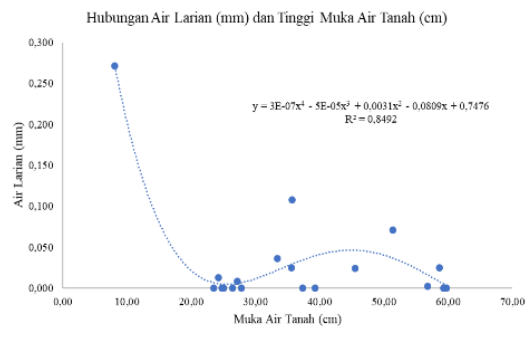

Gambar 6. Hubungan air larian dengan tinggi muka air tanah 
Berdasarkan Gambar 6, karena data pengukuran berfluktuasi, maka fluktuasi tinggi muka air tanah akan mempengaruhi air larian yang terjadi, sehingga hubungan antara air larian dengan tinggi muka air tanah cukup besar. Ditunjukkan dengan nilai $\mathrm{R}^{2}$ sebesar 0,85 .

\section{KESIMPULAN DAN SARAN}

\section{Kesimpulan}

Kesimpulan dari penelitian ini adalah :

1. Air larian rata-rata selama 20 hari kejadian adalah sebesar $0,0292 \mathrm{~mm}$.

2. Terdapat hubungan yang signifikan antara curah hujan dengan air larian, semakin besar curah hujan maka semakin besar air larian yang terjadi. Sehingga air larian sangat bergantung dari curah hujan yang terjadi. Terlihat dari nilai $\mathrm{R}^{2}$ sebesar 0,92 .

3. Hubungan antara air larian dengan tinggi muka air tanah cukup besar, Semakin kecil tinggi muka air tanah, maka semakin besar air larian yang terjadi, sehingga fluktuasi tinggi muka air tanah mempengaruhi air larian yang terjadi. Ditunjukkan dengan nilai $\mathrm{R}^{2}$ sebesar 0,85 .

\section{Saran}

Saran dari penelitian ini adalah :

1. Penelitian dilakukan dari akhir bulan Juni hingga awal bulan November di mana pada bulan tersebut merupakan musim kemarau, jadi untuk penelitian air larian yang sangat mengandalkan hari hujan menjadi sangat terbatas. Kondisi lahan ditutupi semak ilalang dan tanaman paku-pakuan yang kemudian dibersihkan untuk memudahkan penelitian. Untuk itu disarankan dilakukan penelitian air larian pada musim hujan dan pada kondisi lahan yang berbeda.

2. Plot yang digunakan merupakan plot sederhana menggunakan bak dari ember, papan-papan bekas, dan spanduk bekas. Diharapkan pada penelitian selanjutnya supaya lebih memperhatikan komponenkomponen pemasangan plot, agar data yang didapatkan lebih baik dan mudah dikumpulkan.

\section{DAFTAR PUSTAKA}

Aldrian, E, Budiman \& Karmini, M. 2011. Adaptasi dan Mitigasi Perubahan Iklim di Indonesia. Pusat Perubahan Iklim dan Kualitas Udara Kedeputian Bidang Klimatologi. Jakarta: Badan Meteorologi, Klimatologi dan Geofisika.

Anonim. 1986. Pedoman Penyusunan Pola Rehabilitasi Lahan dan Konservasi Tanah. Direktorat Jendral Reboisasi dan Rehabilitasi Lahan. Jakarta: Departemen Kehutanan.

Anonim. 2018. Kota Palangka Raya dalam Angka Tahun 2018. Palangka Raya: Badan Pusat Statistik.

Arsyad, Sitanala. 2010. Konservasi Tanah dan Air. Edisi Kedua. IPB Press. Bogor.

Asdak, Chay. 1995. Hidrologi dan Pengelolaan Daerah Aliran Sungai. Yogyakarta: Gadjah Mada University Press.

Asdak, Chay. 2010. Hidrologi dan Pengelolaan Daerah Aliran Air Sungai: Edisi Revisi Kelima. Yogyakarta: Gadjah Mada University Press.

Ebisemiju, F. S. 1990. Sediment Delivery Ratio Prediction Equations for Short Catchment Slopes in a Humid Tropical Environment. J. of Hydrology, 114: 191-208.

Hidayat, Y. 2001. Aplikasi Model ANSWERS dalam Memprediksi Erosi dan Aliran Permukaan di DTA Bodong Jaya dan DAS Way Besay Hulu, Lampung Barat [tesis]. Bogor: Sekolah Pasca Sarjana, Institut Pertanian Bogor.

Joyce Martha, W. dan Wanny Adidarma. 1982. Mengenal Dasar-dasar Hidrologi. Bandung: Nova.

Manullang, S, V. 2013. Modifikasi Penakar Hujan Otomatis Tipe Tipping Bucket dengan Hall Effect Sensor ATS276. Sumatera Utara: Universitas Sumatera Utara.

Miller, S. 1994. Hanbook fo Agrohydrology. UK: Natural Resources Institute. Chatam.

Rahim, SE. 2000. Pengendalian Erosi Tanah dalam Rangka Pelestarian Lingkungan Hidup. Jakarta: Bumi Aksara.

Schwab, G.O., R.K. Frevert, T.W. Edminster, dan K.K.Barnes. 1982. Soil and Water 
Conservation Engineering. 3rd ed. John Wiley \& Sons, New York.

Sinun, W. Douglas, I. Spencer, T. Greer, T. Bidin, K. \& Wong, W. M. 1992. The Impact of Selective Commercial Logging on Stream Hydrology, Chemistry and Sediment Loads in the Ulu Segama Rain Forest, Sabah. Phil Trans. R. Soc. Lond. B 335, 397-406.

Tjasyono, Bayong HK. 2006. Klimatologi. Bandung: Penerbit ITB.

Van Thijn, A, Kobus, M.L, dan Rawuh, Rd, 1953. Ilmu Ukur Ruang, J.B Wolters, Jakarta.

Wesli. 2008. Drainase Perkotaan. Yogyakarta: PT. Graha Ilmu.

Wischmeier, WH, Smith, DD. 1978. Predicting Rainfall Erosion Losses. Agric Hanb. 573. Washington DC: Agriculture Research Service.

Ziliwu. 2002. Pengaruh Beberapa Macam Tanaman Terhadap Aliran Permukaan dan Erosi. Semarang : Program Pasca Sarjana, Universitas Diponegoro. 